\title{
QSAR Studies of some New Synthesized Diacylhydrazine Compounds Derived from Indomethacin as Caspase-1 Inhibitors
}

\author{
Kawther H. Al-Naimi Haitham A. A-Alwahb Hyffaa Y. Hussien \\ Department of Chemistry/ College of Science/ University of Mosul
}

(Received 11/11/2013;Accepted 20/1/2014)

\begin{abstract}
Indomethacin (1) reacts with absolute ethanol in presence of conc. sulphuric acid to form the ester (2). This ester was converted into the hydrazide (3) by treatment with hydrazine hydrate. The reaction of the hydrazide (3) with acid chlorides (of indomethacine, dichlofenac, mefenamic acid, aspirin and ibuprofen) in dry xylene afforded the $N, N$ '-diacylhydrazine compounds (4-8). A series of new 2,5-disubstituted-1,3,4-oxadiazoles (9-13) derived from indomethacin (1) was obtained by the dehydrative cyclization of the corresponding $N, N^{\prime}$-diacylhydrazines(4-8), in presence of an excess of thionyl chloride. The quantitative structure-activity relationship (QSAR) analysis of the synthesized compounds was also performed to compute the parameters that affect the biological activity (inhibitory activity $\mathrm{IC}_{50}$ ). Docking analysis was also performed to predict the interactions between the synthesized compounds with Caspase-1 (Interleukin-1 converting enzyme). The study is aimed to predict factor affecting the biological activity of the prepared compounds by employing the QSAR analysis. The structures of the synthesized compounds were confirmed by the spectroscopic methods.
\end{abstract}

Keywords: Indomethacin, $N$, N'-diacylhydrazine, 2,5-disubstituted-1,3,4-oxadiazoles, QSAR and docking.

\section{درلسة QSAR لعدمن مركبلت شنائي الاسل هيرازين الجية المشقةمن}

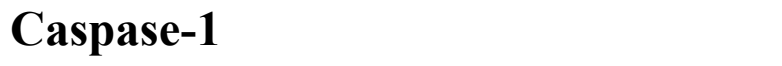

\section{الملذص}

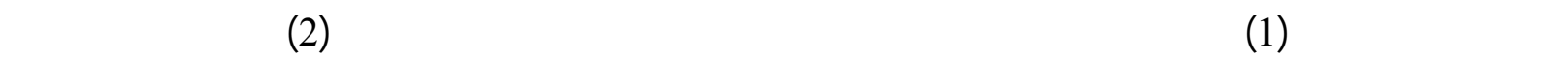

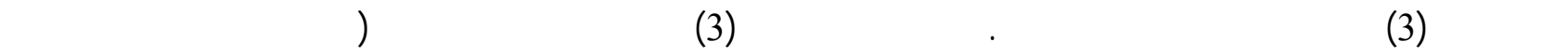

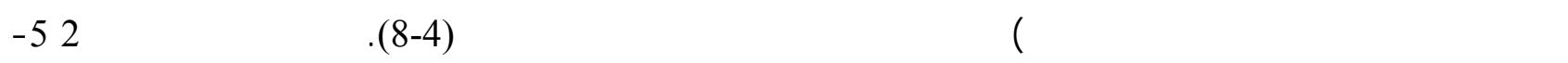

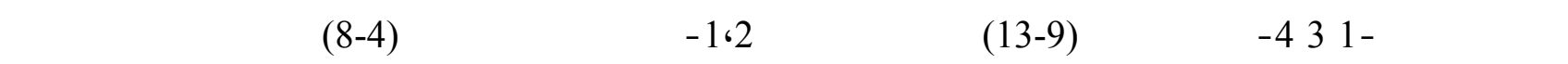

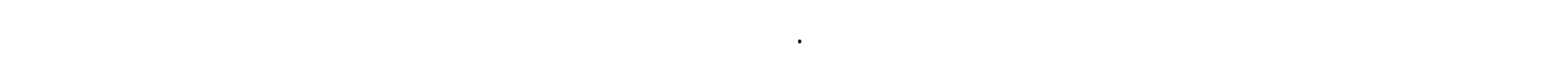

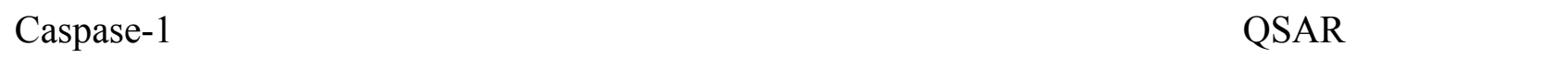

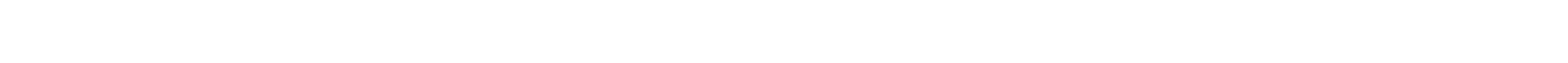

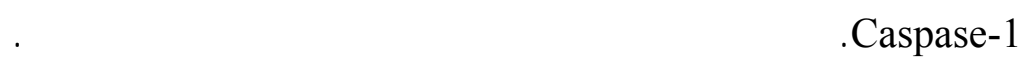

الكلملت الدالة: إندوميثلسن، وال ـ Docking 


\section{INTRODUCTION}

The 2,5-disubstituted-1,3,4-oxadiazole compounds have been reported to be remarkable antidepressive (Almasirad et al., 2004), anticonvulsive (Kashaw et al., 2010), antihypertensive (Bankar et al., 2004), anti-inflammatory (Chandra et al., 2010), antiviral (Wang et al., 2012), antitumor (Savariz et al., 2010), antimicrobial agents (Oliveira et al., 2012), as well as insecticides (Shi et al., 2001). Moreover, they have an interesting electrochemical (Yasuda et al., 2005) and fluorescent properties (Agbaria and Gill, 1994). $N, N^{\prime}$-diacylhydrazines are easily accessible starting from acids, acid chlorides or esters and respectively various hydrazides (Dingemans et al., 2001) and are valuable intermediates in the synthesis of cyclic compounds. The most common synthetic strategy for preparing 2,5-substituted-1,3,4-oxadiazoles involves the dehydrative cyclization of $N, N$ 'diacylhydrazines using dehydration agents such as $\mathrm{POCl}_{3}$ (Amir and Kumar, 2007), $\mathrm{SOCl}_{2}$ (Hernández-Ainsa et al., 2012) or $\mathrm{P}_{2} \mathrm{O}_{5}$ (Carlsen and Jorgensen, 1994). The present work is concerned with the preparation of compounds from $N, N$ '-diacylhydrazines containing indomethacin moiety and studying its biological activity as Caspase-1 inhibitor by using quantitative structure activity relationship (QSAR). On the other hand, the QSAR is considered one of the most important field in medicinal chemistry, giving useful information applied to drug design. QSAR models are mathematical equations relating chemical structure to a wide variety of physical, chemical and biological properties. The derived relationship between molecular descriptors and activity is used to estimate the property of other molecules and/or to find the parameters affecting the biological activity (Hansch, 1969).

\section{EXPERIMENTAL}

Melting points were determined on an electrothermal IA 9300 Digital-series (1998) apparatus, and they were uncorrected. Infrared spectra were recorded on a Bruker FT-IR spectrophotometer Tensor 27, Germany (College of Education, Mosul University). UV spectra were recorded on a Shimadzu UV/Vis-1650 pc spectrophotometer using chloroform as a solvent (College of Science, Mosul University).

The QSAR study was performed using the previously reported biological activity values $\left(\mathrm{IC}_{50}\right.$ $\mathrm{nM}$ ) (Soper et al., 2006). These values are used as dependent variables. The physicochemical properties [i.e. Lipophilic (CLogP) and Electrostatic (Chemical hardness $\eta)$ ] were calculated using $\mathrm{AM}_{1}$ as an independent variable in linear regression analysis, then the QSAR models were designed using SPSS (11.5) program. The docking process was carried out using iGEMDOCK v.2.1 program.

\section{Synthesis of ethyl [1-(4-chlorobenzoyl)-2-methyl-5-methoxy-1H-indol-3-yl] acetate (2). General method (Euranto, 1969):}

To a solution of Indomethacin (1) $(0.1$ mole, $35.75 \mathrm{~g})$ in $100 \mathrm{ml}$ absolute ethanol, $10 \mathrm{ml}$ of conc. sulfuric acid was slowly added at room temperature. The reaction mixture was refluxed for $6 \mathrm{hr}$. The contents of the flask were allowed to cool to room temperature, then poured onto crushed ice and neutralized with $20 \%$ sodium bicarbonate solution. The slurry oil was extracted with benzene. The organic layer was dried over anhydrous magnesium sulphate, filtered off and evaporated under reduced pressure to give semi solid product, which recrystallized from n-heptane to give white bright needle crystals; m.p $70-72{ }^{\circ} \mathrm{C}$ in $90 \%$ yield. ${ }^{1} \mathrm{H}-\mathrm{NMR}$ (200 MHz, DMSO-d6) $\delta$ ppm: 1.15 (t, $\left.\mathrm{CH}_{2}-\mathrm{CH}_{3}\right), 4.08$ (q, $\left.\mathrm{CH}_{2}-\mathrm{CH}_{3}\right), 2.3\left(\mathrm{~s}, \mathrm{CH}_{3}\right), 3.6\left(\mathrm{~s}, \mathrm{CH}_{2}\right), 3.75\left(\mathrm{~s}, \mathrm{OCH}_{3}\right), 6.6-7.15(\mathrm{~m}$, $7 \mathrm{H}, \mathrm{Ar}-\mathrm{H})$. IR (KBr pellets) $v \mathrm{~cm}^{-1}: 1711(\mathrm{C}=\mathrm{O}$ str., ester $), 1626(\mathrm{C}=\mathrm{O}$ str., ter. amide $), 1589(\mathrm{C}=\mathrm{C}$ str.), 3003 (C-H str., aromatic), 2976 (C-H str., aliphatic), 793 (C-Cl str.). U.V $\left(\mathrm{CHCl}_{3}\right) \lambda \mathrm{nm}: 284$ $\left(\mathrm{n} \rightarrow \pi^{*}\right), 250\left(\pi \rightarrow \pi^{*}\right)$ electronic transition. 
Synthesis of [1-(4-chlorobenzoyl)-2-methyl-5-methoxy-1H-indol-3-yl] acetic acid hydrazide (3).

General method (Amir and Shikha, 2004):

To a solution of ester (2) ( 0.1 mole, $38.55 \mathrm{~g})$ in $100 \mathrm{ml}$ absolute ethanol, hydrazine hydrate $(0.5$ mole, $7.26 \mathrm{ml}$ ) (the hydrazine hydrate $(80 \%)$ was freshly distilled in presence of sodium hydroxide) was added and the reaction mixture was refluxed for $48 \mathrm{hr}$. The precipitate was separated on cooling and collected by filtration, then recrystallized from dry benzene to afford the hydrazide (3) as white bright crystals; m.p 161-163 ${ }^{\circ} \mathrm{C}$ in $93 \%$ yield. ${ }^{1} \mathrm{H}-\mathrm{NMR}(200 \mathrm{MHz}$, DMSO-d6) $\delta$ ppm: 2.2 $\left(\mathrm{s}, \mathrm{CH}_{3}\right), 3.4\left(\mathrm{~s}, \mathrm{CH}_{2}\right), 3.75\left(\mathrm{~s}, \mathrm{OCH}_{3}\right), 4.35\left(\mathrm{br}, \mathrm{NH}_{2}\right), 6.6-7.15(\mathrm{~m}, 7 \mathrm{H}, \mathrm{Ar}-\mathrm{H}), 10.58(\mathrm{~s}, \mathrm{NH}$, amide). IR (KBr disk) $\vee \mathrm{cm}^{-1}: 1654$ ( $\mathrm{C}=\mathrm{O}$ str., amide), 1631 ( $\mathrm{C}=\mathrm{O}$ str., ter. amide), 1594 (C C str.), 3282 (N-H str., amide), 3300 ( $\mathrm{NH}_{2}$ str.), 3014 (C-H str., aromatic), 2907 (C-H str., aliphatic), 794 (C-Cl str.). U.V $\left(\mathrm{CHCl}_{3}\right) \lambda \mathrm{nm}: 278\left(\mathrm{n} \rightarrow \pi^{*}\right), 246\left(\pi \rightarrow \pi^{*}\right)$.

Synthesis of diacylhydrazine compounds (4-8) (Al-Hamdany, 2009):

To a solution of an acid (indomethacine, dichlofenac, mefenamic acid, aspirin or ibuprofen) $(0.01 \mathrm{~mole})$ in $20 \mathrm{ml}$ of dry benzene, $(0.013$ mole, $1.53 \mathrm{~g})$ of thionyl chloride was slowly added then the reaction mixture refluxed for $4 \mathrm{hr}$. The mixture (benzene and excess of thionyl chloride) was evaporated under reduced pressure to dryness. To the solid residue, a solution of acylhydrazine (3) $(0.015$ mole, $5.565 \mathrm{~g})$ in $40 \mathrm{ml}$ of dry xylene and $(0.01 \mathrm{~mole}, 0.82 \mathrm{ml})$ dry pyridine was added. The reaction mixture was stirred under reflux for $60 \mathrm{~min}$. The resulted precipitate was filtered off and washed with water, dried and recrystallized from a mixture of ethyl acetate and ether or petroleum ether (80-100) ${ }^{\circ} \mathrm{C}$. The physical properties and spectral data of compounds (4-8) were listed in (Table 1).

Synthesis of the oxadiazoles (9-13) (Kumar et al., 2010):

To a suspension of ( 0.01 mole) of $N, N^{\prime}$-diacylhydrazine $(4-8)$ in $(5 \mathrm{ml})$ thionyl chloride, $(0.5 \mathrm{ml})$ dry pyridine were added dropwise. The mixture was stirred at room temperature overnight, then refluxed for $30 \mathrm{~min}$. The pyridine and the remained thionyl chloride were removed under vacuum. The remained residue was recrystallized from ethanol to give pure products (9-13). The physical properties and spectral data of compounds (9-13) were listed in (Table 1).

\section{RESULTS AND DISCUSSION}

Ethyl [1-(4-chlorobenzoyl)-2-methyl-5-methoxy -1H-indol-3-yl] acetate (2) was obtained via Buchman synthesis using indomethacin in presence of concentrated sulphuric acid as catalyst in ethanolic solution (Euranto, 1969). The $\alpha$-(3-indomethacin) acetyl hydrazine (3) was synthesized by condensation of indomethacin ester (compound 2) with hydrazine hydrate in absolute ethanol. The IR spectrum of the hydrazide (3) showed the disappearance of carbonyl ester absorption band at $\left(1711 \mathrm{~cm}^{-1}\right)$ and appearance of strong absorption band at $\left(1654 \mathrm{~cm}^{-1}\right)$ and medium absorption band at $\left(1631 \mathrm{~cm}^{-1}\right)$ due to the carbonyl hydrazide and tertiary carbonyl amide, respectively. The key intermediates for synthesis of 2,5-disubstituted-1,3,4-oxadiazoles (9-13) are the $N, N^{\prime}$ diacylhydrazines (4-8), which were formed as a result of the reaction of the acid chloride of (indomethacine, dichlofenac, mefenamic acid, aspirin or ibuprofen) and the hydrazide $\mathbf{3}$, in dry xylene across the tetrahedral mechanism: 


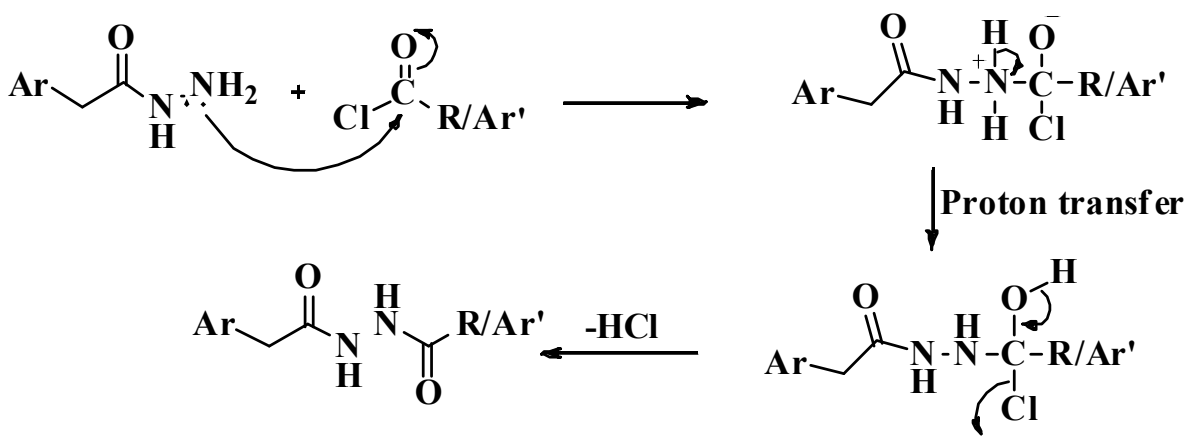

The 2,5-disubstituted-1,3,4-oxadiazoles was synthesized by refluxing of $N, N$ '-diacylhydrazines with an excess of $\mathrm{SOCl}_{2}$ in dry xylene, according to following suggested mechanism:

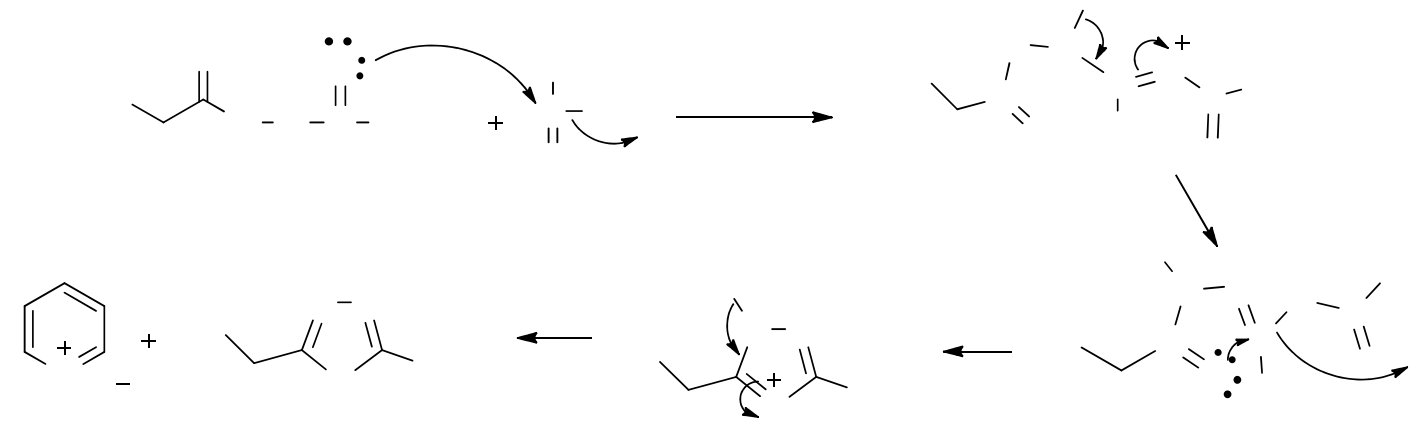

The structures of compounds (9-13) were confirmed by physical and spectral data. The I.R. spectrum showed the new absorption bands at $\left(1606-1620 \mathrm{~cm}^{-1}\right)$ due to the $(\mathrm{C}=\mathrm{N})$ bond stretching.

The QSAR study was performed using the calculation of lipophilicity $(\mathrm{Clog} P)$ and Electrostatic (Chemical hardness $\eta$ ) as shown in (Table 2) as independent variables in Linear regression analysis which give a QSAR models as shown in equation (1) for 13 compounds described in (Table 2) to obtain inhibitory activity $\mathrm{IC}_{50}$ toward Caspase-1 (Interleukin-1 converting enzyme) the target is Homo sapiens.

$$
\mathrm{IC}_{50}=-3886.37+94.18 * \operatorname{CLog} \mathrm{P}+911.00 * \eta
$$

$(\mathrm{n}=13$; correlation coefficient $(r)=0.913)$

$\eta=(\mathrm{E}$ LUMO $-\mathrm{E}$ HOMO $) / 2$

The best biological activity of the synthesized compounds as Caspase-1 inhibitor was exhibited by compound 7 as shown in Table (3while for the proposed compounds (14-23), the best biological activity as Caspase-1 inhibitor was exhibited by mpound 17 as shown in Table (5).

\section{Ar $\quad$ H}

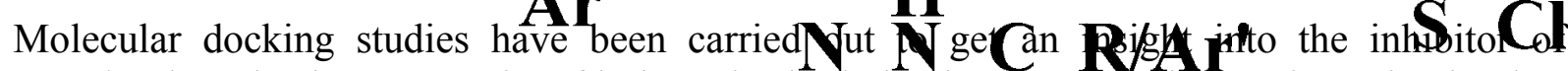
Caspase-1 by the selective antagonist of indomethacin derivative compounds. Our investigation has shown that the best docking energy is $-138.991 \mathrm{kcal} / \mathrm{mol}$ for the synthetic compound $($ with Caspase-1 as shown in Table (4) (VDW: Vander Waals, H bond: Hydrogen bond. 
Table 1: The physical properties and spectral data for compounds 4-13.

\begin{tabular}{|c|c|c|c|c|c|c|c|c|}
\hline \multirow[b]{2}{*}{$\begin{array}{l}\text { Comp. } \\
\text { No. }\end{array}$} & \multirow[b]{2}{*}{ Colour } & \multirow[b]{2}{*}{ m.p ${ }^{\circ} \mathbf{C}$} & \multirow[b]{2}{*}{$\begin{array}{c}\text { Yield } \\
\%\end{array}$} & \multirow[b]{2}{*}{$\begin{array}{c}\mathrm{U} . \mathrm{V} \\
\left(\mathrm{CHCl}_{3}\right) \\
\lambda \mathrm{nm}\end{array}$} & \multicolumn{4}{|c|}{ IR (KBr) v cm ${ }^{-1}$} \\
\hline & & & & & $\begin{array}{c}C=O \\
\text { sec.amide }\end{array}$ & $\mathbf{C}=\mathbf{N}$ & $\begin{array}{c}C=O \\
\text { ter.amide } \\
C=-C\end{array}$ & $\begin{array}{l}\mathrm{C}-\mathrm{Cl} \\
\mathrm{N}-\mathrm{H}\end{array}$ \\
\hline 4 & white & $301-303$ & 75 & $\begin{array}{l}218 \\
248^{*}\end{array}$ & 1685 & & $\begin{array}{c}1601 \\
1466-1597\end{array}$ & $\begin{array}{c}756 \\
3186 \\
\end{array}$ \\
\hline 5 & $\begin{array}{l}\text { Reddish- } \\
\text { orange }\end{array}$ & $311-313$ & 28 & $\begin{array}{l}246 \\
268^{*} \\
\end{array}$ & 1690 & & $\begin{array}{c}1601 \\
1471-1560 \\
\end{array}$ & $\begin{array}{c}742 \\
3201 \\
\end{array}$ \\
\hline 6 & Pink & $258-260$ & 37 & $\begin{array}{l}220 \\
256^{*}\end{array}$ & 1680 & & $\begin{array}{c}1637 \\
1458-1558 \\
\end{array}$ & $\begin{array}{r}756 \\
3238 \\
\end{array}$ \\
\hline 7 & Yellow & $241-243$ & 15 & $\begin{array}{l}222 \\
250^{*}\end{array}$ & $\begin{array}{c}1684 \\
1735 \text { (ester) }\end{array}$ & & $\begin{array}{c}1637 \\
1457-1600\end{array}$ & $\begin{array}{c}762 \\
3236 \\
\end{array}$ \\
\hline 8 & white & $298-300$ & 17 & $\begin{array}{l}225 \\
244^{*}\end{array}$ & 1685 & & $\begin{array}{c}1647 \\
1466-1601 \\
\end{array}$ & $\begin{array}{c}742 \\
3221 \\
\end{array}$ \\
\hline 9 & white & $251-253$ & 60 & $\begin{array}{l}239 \\
302^{*}\end{array}$ & & 1606 & $\begin{array}{c}1637 \\
1458-1554\end{array}$ & 739 \\
\hline 10 & Pale-pink & $248-250$ & 94 & $\begin{array}{l}244 \\
294^{*}\end{array}$ & & 1616 & $\begin{array}{c}1643 \\
1489-1598 \\
\end{array}$ & $\begin{array}{c}748 \\
3240 \\
\end{array}$ \\
\hline 11 & Brown & $177-180$ & 86 & $\begin{array}{l}222 \\
246^{*}\end{array}$ & & 1606 & $\begin{array}{c}1675 \\
1466-1575 \\
\end{array}$ & 748 \\
\hline 12 & gray & $145-148$ & 78 & $\begin{array}{l}246 \\
282^{*} \\
\end{array}$ & $1757 /$ ester & 1620 & $\begin{array}{c}1647 \\
1466-1598 \\
\end{array}$ & 748 \\
\hline 13 & white & $252-254$ & 80 & $\begin{array}{l}225 \\
246^{*}\end{array}$ & & 1610 & $\begin{array}{c}1647 \\
1487-1575\end{array}$ & 754 \\
\hline
\end{tabular}

$*=$ refer to $\left(\lambda_{\max }\right) \quad\left(\mathrm{n} \longrightarrow \pi^{*}\right)_{\mathbf{O}}$
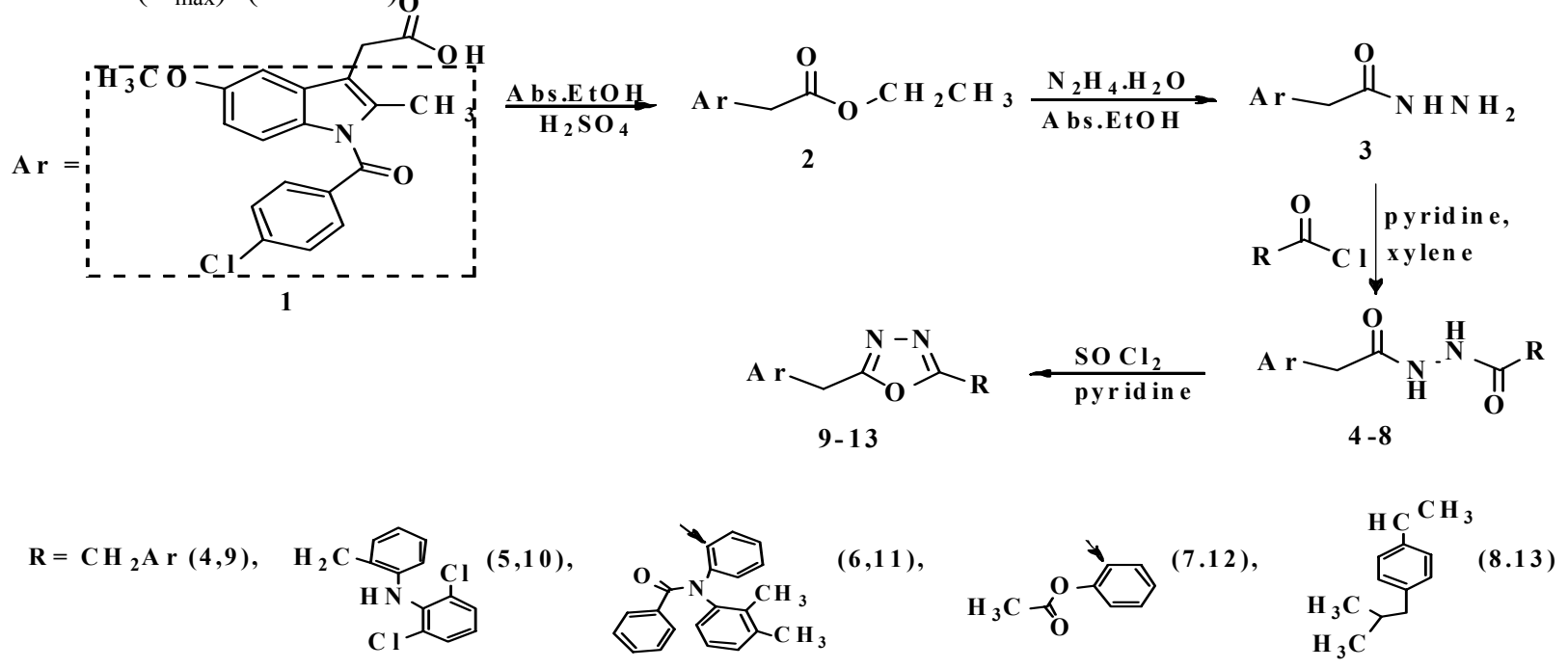

Scheme 1: Synthesis of some $N, N^{\prime}$-diacylhydrazines Linked to 2,5-disubstituted-1,3,4oxadiazoles. 
Table 2: Biological activity data of compounds reported in literature (Soper et al., 2006) and physicochemical properties

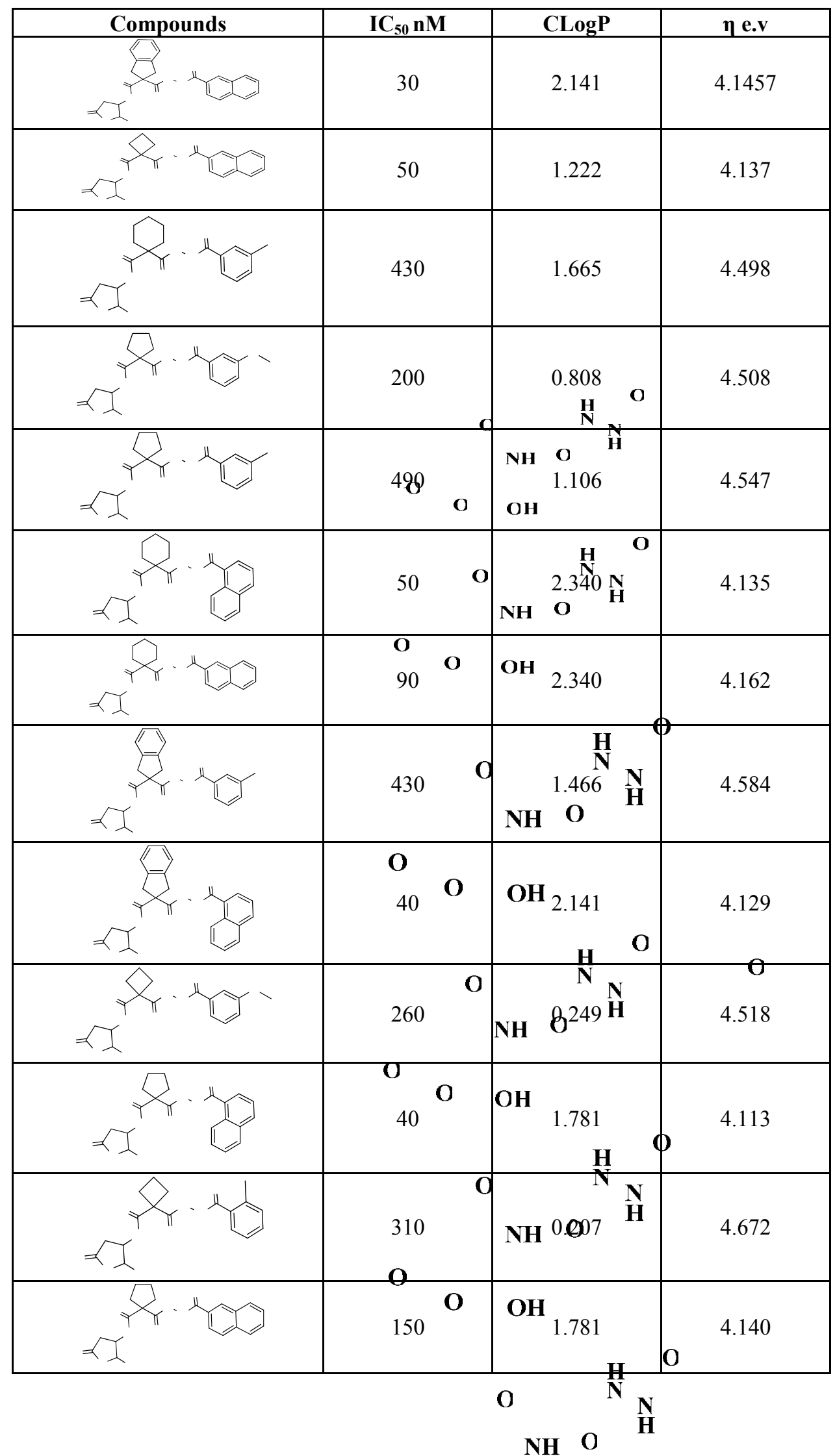

$\mathbf{O}$

O OH

$0 \quad \stackrel{\mathrm{N}}{\mathrm{N}}_{\mathrm{H}}^{\mathrm{O}}$ 
Table 3: Biological activity and physicochemical data as Caspase-1 inhibitors

\begin{tabular}{|c|c|c|c|c|}
\hline Compds. & Mol.Wt. & CLog $\mathbf{P}$ & $\boldsymbol{\eta}$ e.v & IC $_{\mathbf{5} \mathbf{~}}$ M \\
\hline $\mathbf{4}$ & 711.59 & 7.789 & 3.774 & 285.513 \\
\hline $\mathbf{5}$ & 649.95 & 8.336 & 3.743 & 308.522 \\
\hline $\mathbf{6}$ & 699.19 & 8.426 & 3.853 & 417.400 \\
\hline $\mathbf{7}$ & 533.96 & 4.406 & 3.861 & 46.230 \\
\hline $\mathbf{8}$ & 546.06 & 6.703 & 3.878 & 277.435 \\
\hline
\end{tabular}

Table 4: Docking analysis for synthetic compounds

\begin{tabular}{|c|c|c|c|}
\hline Compds. & Energy kcal/mol & VDW kcal/mol & H.Bond kcal/mol \\
\hline $\mathbf{4}$ & -138.991 & -128.923 & -10.068 \\
\hline $\mathbf{5}$ & -117.770 & -107.363 & -10.407 \\
\hline $\mathbf{6}$ & -118.609 & -116.421 & -2.188 \\
\hline $\mathbf{7}$ & -100.457 & -71.567 & -28.890 \\
\hline $\mathbf{8}$ & -104.559 & -94.028 & -10.531 \\
\hline
\end{tabular}

Table 5: Biological activity and physicochemical data of proposed compounds

\begin{tabular}{|c|c|c|c|c|c|}
\hline No. & Compds. & Mol.Wt. & CLog P & $\eta$ e.v & $\mathrm{IC}_{50} \mathrm{nM}$ \\
\hline 14 & & 683.54 & 6.618 & 3.865 & 258.274 \\
\hline 15 & & 434.49 & 3.178 & 4.139 & 183.430 \\
\hline 16 & & 609.11 & 7.500 & 3.746 & 232.266 \\
\hline 17 & & 581.06 & 6.502 & 3.640 & 41.596 \\
\hline 18 & & 595.09 & 8.016 & 3.856 & 381.261 \\
\hline 19 & & 671.14 & 7.878 & 3.830 & 344.715 \\
\hline 20 & & 491.92 & 5.467 & 3.868 & 152.352 \\
\hline 21 & & 489.95 & 5.004 & 3.871 & 111.226 \\
\hline 22 & & 532.03 & 6.361 & 3.865 & 234.069 \\
\hline 23 & & 518.00 & 5.832 & N 3831 & 153.261 \\
\hline
\end{tabular}

N

Cl

o 0

HN NH 


\section{Table 6: Docking analysis for proposed compounds}

\begin{tabular}{|c|c|c|c|}
\hline No. & $\begin{array}{c}\text { Energy } \\
\mathbf{k c a l} / \mathbf{m o l}\end{array}$ & $\begin{array}{c}\text { VDW } \\
\mathbf{k c a l} / \mathbf{m o l}\end{array}$ & H.Bond kcal/mol \\
\hline $\mathbf{1 4}$ & -116.103 & -94.747 & -21.357 \\
\hline $\mathbf{1 5}$ & -99.450 & -78.147 & -21.303 \\
\hline $\mathbf{1 6}$ & -103.660 & -93.419 & -10.241 \\
\hline $\mathbf{1 7}$ & -119.742 & -105.742 & -14.000 \\
\hline $\mathbf{1 8}$ & -122.261 & -119.148 & -3.113 \\
\hline $\mathbf{1 9}$ & -124.683 & -116.799 & -7.884 \\
\hline $\mathbf{2 0}$ & -94.983 & -76.044 & -18.939 \\
\hline $\mathbf{2 1}$ & -105.264 & -99.264 & -6.000 \\
\hline $\mathbf{2 2}$ & -109.420 & -101.950 & -7.470 \\
\hline $\mathbf{2 3}$ & -107.346 & -101.124 & -6.222 \\
\hline
\end{tabular}

\section{ACKNOWLEDGEMENTS}

The authors are thankful to the dean of Sci. Coll., Univ. Mosul and to the head of Chem. Dept. for providing finance for spectral measurement.

\section{REFERENCES}

Agbaria, A.R.; Gill, D. (1994). Non-covalent polymers of oxadiazole derivatives induced by $\gamma$ cyclodextrin in aqueous solutions- flourescence study. J. Photochem. Photobiol. A: Chem., 78(2), 161-167.

Al-Hamdany, F.K.I. (2009). Synthesis of some(S)-2-(6'-methoxy-2'-naphthyl) propanoic acid derivatives (Naproxen). Ph. D. Thesis, University of Mosul, Mosul-Iraq, 47.

Almasirad, A.; Tabatabai, S.A.; Faizi, M.; Kebriaeezadeh, A.; Mehabi, N.; Dalvandi A.; Shafiee, A. (2004). Synthesis and anti convulsant activity of new 2-substituted 5-[2-(2flurophenoxy)phenyl]-1,3,4-oxadiazole and 1,2,4-triazoles. Bioorg. Med. Chem. Lett. 4(14), 6057-6059.

Amir, M.; Kumar, S. (2007). Synthesis and evaluation of anti-inflammatory, analgesic ulcerogenic and lipid peroxidation properties of ibuprofen derivatives. Acta Pharm., 57,31-45.

Amir, M.; Shikha, K. (2004). Synthesis and anti-inflammatory, analgesic, ulcerogenic and lipid peroxidation activities of some new 2-[(2,6-dichloroanilino) phenyl]acetic acid derivatives. Eur. J. Med. Chem., 39,535.

Athayde-Filho, P.F. (2012). Synthesis, molecular properties prediction, and anti-staphylococcal activity of $\mathrm{N}$-acylhydrazones and new 1,3,4-oxadiazole derivatives. Molecules, 17, 50955107.

Bankar, G.R.; Nandakumar, K.; Nayak, P.G.; Thakur, A.; Chamallamudi, M.R.; Nampurath, G.K. (2009). Vasorelaxant effect in rat aortic rings though calcium channel blockage: A preliminary in vitro assessment of a 1,3,4-oxadiazole derivative. Chem. Biol. Interact., 181, 377-382.

Carlsen, P.H.J.; Jorgensen, K.B. (1994). Synthesis of Unsymmetrically Substituted 4H-1, 2, 4Triazoles. J. Heterocycl. Chem.,31, 805.

Chandra, T.; Garg, N.; Lata, S.; Saxena K.K.; Kumar, A. (2010). Synthesis of substituted acridinyl pyrazoline derivatives and their evaluation for anti-inflammatory activity, Eur. J. Med. Chem., 45,1772-1776.

Dingemans, T.J.; Murthy, N.S.; Samulski, E.T. (2001). Javelin-, Hockey Stick-, and BoomerangShaped Liquid Crystals. Structural Variations on p-Quinquephenyl. J. Phys. Chem., 105, 8845-8860.

Euranto, E.K. (1969). "The Chemistry of Carboxylic Acids and Esters, Wiley-Interscience". in S. Patai, ed., New York, Chapt. 11.

Hansch, C. (1969). A quantitative approach to biochemical structure- activity relationships. Acc. Chem. Res., 2,232-239. 
Hernández-Ainsa, S.; Barberá, J.; Marcos, M.; Serrano, J.L. (2012). Liquid crystalline ionic dendrimers containing luminescent oxadiazole moieties. Macromolecules, 45,1006-1015.

Husain, A.; Ahmad, A.; Alam, M.M.; Ajmal, M.; Ahuja, P. (2009). Fenbufen based 3-[5-substituted aryl)-1,3,4-oxadiazol-2-yl)]-1-(biphenyl-4-yl)propan-1-ones as safer anti-inflammatory and analgesic agents. Eur. J. Med. Chem., 44, 3798-3804.

Kashaw, S.K.; Gupta, V.; Kashaw, V.; Misha, P.; Stables, J.P.; Jain, N.K. (2010). Anticonvulsant and sedative-hypnotic activity of some novel 3-[5-(4-substituted) phenyl-1,3,4-oxadiazole2yl]-2-styrylquinazoline-4(3H)-ones. Med. Chem. Res., 19, 250-261.

Kumar, G.V.S.; Rajendraprasad, Y.; Mallikarjuna, B.P.; Chandrashekar, S.M.; Kistayya, C. (2010). Synthesis of some novel 2-substituted-5-[isopropylthiazole] clubbed 1,2,4-triazole and 1,3,4oxadiazoles as potential antimicrobial and antitubercular agents. Eur. J. Med. Chem., 45, 2063-2074.

March, J. (1977). "Advanced Organic Chemistry: Reactions, Mechanisms and Structure". 2nd edn, McGraw-Hill Book Co., Japan, 307 p.

Oliveira, C.S.; Lira, B.F.; Falcão-Silva, V.S.; Siqueira-Junior, J.P.; Barbosa-Filho, J.M.; Savariz, F.C.; Formagio, A.S.N.; Barbosa, V.A.; Foglio, M.A. Carvalho, J.E.; Duarte, M.C.T.; Filho, B.P.D.; Sarragiotto, M.H. (2010). Synthesis, antitumor and antimicrobial activity of novel 1-substituted phenyl-3-[3-alkylamino(methyl)-2-thioxo-1,3,4-oxadiazol-5-yl]-b-carboline derivatives. J. Braz. Chem. Soc., 21, 288-298.

Shi, W.; Qian, X.; Zhang, R.; Song, G. (2001). Synthesis and Quantitative Structure-Activity Relationships of New 2,5-Disubstituted-1,3,4-oxadiazoles. J. Agric. Food Chem., 49(1),124130.

Soper, D.L.; Shevile, J.; O'Neil, S.V.; Wang, Y.; Laufersweiler, M.C.; Oppong, K.A.; Wos, J.A.; Ellis, C.D.; Fancher, A.N.; Lu, W.; Suchanek, M.K.; Wang, R.L.; De, B.; Demuth, T.P. (2006). Synthesis and evaluation of novel 1-(2-acylhydrazinocarbonyl)-cycloalkyl carboxamides as interleukin-1beta converting enzyme (ICE) inhibitors. Bioorg. Med. Chem. Lett., 16(16), 4233-4236.

Wang, Z.; Wang, M.; Yao, X.; Li, Y.; Qiao, W.; Geng, Y.; Liu, Y.; Wang, Q. (2012) Hydroxyl may not be indispensable for raltegravir: Design, synthesis and SAR studies of raltegravir derivatives as HIV-1 inhibitors. Eur. J. Med. Chem., 50, 361-369.

Yasuda, T.; Imase, T.; Sasaki, Sh.; Yamamoto, T. (2005). Synthesis, solid structure and optical properties of new thiophene-based alternating n-conjugated copolymers containing 4-alkyl1,2,4-triazole or 1,3,4-thiadiazole unit as the parther unit. Macromolecules, 38(1), 1500-1503. 